\title{
Allergenic and Toxic Compounds in Ornamental Plants - A review
}

\author{
Cristina MIRCEA (ARSENE) ${ }^{1 *}$, Lucia DRAGHIA ${ }^{1)}$ \\ ${ }^{1)}$ Department of Floriculture, Faculty of Horticulture, University of Agricultural Sciences and Veterinary \\ Medicine Ion Ionescu de la Brad Iasi, Aleea Mihail Sadoveanu nr. 3, Iaşi, 700490, Romania. \\ ${ }^{*}$ Corresponding authors, e-mails: cris_arsene@yahoo.com
}

Bulletin UASVM Horticulture 71(2) / 2014

Print ISSN 1843-5254, Electronic ISSN 1843-5394

DOI:10.15835/buasvmcn-hort:10470

\begin{abstract}
Various biosynthesised compounds from ornamental plants can be harmful to man, throughout a plant's entire life cycle or only during certain moments, present in all of its organs or restricted only to some. Interdisciplinary research regarding plant toxins and allergens are being conducted worldwide, aiming to prevent the production of diseases. The research aimed to phytochemically classify vegetal compounds with toxic and allergenic characteristics found in ornamental plants, to identify the main pathogenic pathways through which these compounds act and to come up with recommendations regarding valorification of these plants. The study focuses on ornamental plants in both spontaneous and cultivated flora, in protected or unprotected spaces, commonly met in Romania. The current review includes vegetal allergens in the toxic vegetal substances group, from the perspective of modern definitions of toxicity. Based on phytochemical criteria, a classification of toxic vegetal compounds (including allergens) was achieved. Common native toxic ornamentals from our habitat are tabulated. Some non-native species were included on the basis of their high presence as house plants. Correlated to the commercial practices in Romania, the risks for ambient health were identified, both at the work place, at home and in the public space. Ornamentals can be dangerous to man's health. The majority of toxic and allergenic substances (excluding pollens) are secondary metabolism compounds. Given these risk factors to health, it is necessary to impose health and safety regulations at work, to inform the general population regarding potential negative effects and to commercialize plants with labels which should contain warnings about the risk of diseases or the aggravation of existing ones.
\end{abstract}

Keywords: allergenicity, biosecurity, ornamental plants, pathogenicity, toxicity

\section{INTRODUCTION}

Plants have evolved the strategy to produce bioactive natural products as a means of defence against herbivores and pathogenic agents. Some of them produce toxins that can severely damage or kill an herbivore (Wink, 2009). In order to be effective, the defence compounds must be able to interfere with molecular targets of cells, tissues or organs in an herbivore. These toxic principles may cause serious problems to the human body or even death (Wink, 2009; Bernhoft, 2010; Gilbert, 2013).

Ornamental flowering plants could be dangerous in special circumstances related to the plant, way of exposure and potential victim (Piirila, 1994; Crosby, 2004). Usually, undesired effects are registered by accident. Hazardous ornamentals can be harmful through protective structures (Capon, 2011), pollens (Goldberg ei al.,, 1998) and chemical compounds (Gaillard and Pepin, 1999; Lewis, 2003; Wink, 2009). Toxicity, by and large as Kingsbury (2013) underlined, involves an interrelationship among dose, absorbtion, detoxification and excretion. The words "harmful" or "health problems" are anthropocentric. Quality and accessibility of information are central to effective management of all these problems, to prevent and reduce undesired happenings.

Interdisciplinary researches regarding plant toxins and plant allergens are being conducted worldwide (Huntington, 1999; Nelson, 2003; Crosby, 2004; Gilbert, 2004; Prisăcaru and Burlacu, 2005; Wink, 2011; Lăncrăjan, 2012; Rozas-Munõz et al., 2012; Chadwick et al., 2013; Fraga, 2013). 
The aims of these researches are to prevent the occurrence of diseases, to increase economical uses of plants and plants products and to ensure biosecurity in human environment.

This review aims to phytochemically classify the allergenic and toxic compound from Romanian ornamental plants, to identify the main pathways of defined substances, to evaluate hazardous plant risk for human health and to create a local databases of common hazardous ornamentals. In compiling the review article, an extensive literature review was performed by searching internet resources: ISI Web of Science, Medline, Pub Med, Scopus, Google Scholar. Initial searching of these databases was done using specific keywords: 'plant', 'poisoning', 'poison', 'toxicity', 'allergenicity', 'secondary metabolites' to identify relevant articles and books. Further information was obtained from book chapters, relevant new reports and international databases. A focus on selected studies was combined with systematic methods of study-selection and results exploration (Philip, 2009) in order to present the most current researches for the present topic and to develop personal classification and local databases.

\section{DEFINITION OF TOXIC PLANTS AND TOXIC COMPOUNDS IN PLANTS}

Poisonous plants, generally accepted, are those which cause health problems or even death if a quantity of its stem, leaves, flowers, seeds, fruits, roots is ingested (Ionel et al., 2000; Khajja et al., 2011; Lăncrăjan, 2012). Some other plants are normally harmless but its may become toxic in condition of long term exposure or ingestion of high doses of vegetal parts or plant products. Research emphasized (Gaillard and Pepin, 1999; Lewis, 2003; Nelson, 2003; Wink, 2009; Bernhoft, 2010; Jack et al., 2013; Kingsbury, 2013; McGovern and Barkley, 2013) that healthy problems can occur through different ways of exposure: ingestion, inhalation, contact (dermal, mucosal or eye contact). From these perspective, toxic plant, through its chemical compounds "kills, injuries or impairs an organism" (Crosby, 2004). Ornamental toxic plants are beauty plants, possible dangerous for humans, used in ornamental purposes but with different economic uses. These plants are daily companions for florists and horticulturists, being an underestimated occupational hazards (Piirila, 1994; Goldberg et al., 1998; Nelson, 2003;
Crosby, 2004; Le Coz et al., 2011). Ornamentals are large scale used but are not properly labelled from a healthy perspective as Kingsbury (2013) has mentioned.

It has considered that a poison is a substance which, when administrated, inhaled, ingested, touched, is capable to damage or suppressed the normal function of an individual. Poisons cause undesirable effects in living organism. The term of toxic relate to poisonous or deadly effects on the body by breathing, eating, absorbtion or direct contact with a chemical (GHS United Nations, 2011). Natural poisons are produced by species of bacteria, fungi, protists, plants and animals. Plant poisons are bioactive phitochemicals produced as "secondary metabolites" (Wink, 2009; Bernhoft, 2010; Mogoşanu et al., 2012). The major poisonous principles found among plants are organic compounds belonging to different chemical classes. These compounds elicit pharmacological or toxicological effects in man and animals depending on specific factors (Ciulei $e t$ al., 1993; Gavrilescu, 2008; Mogoșanu et al., 2012; Lăncrăjan, 2012). Bioactive natural products have important role in plant evolution and different biological effects (Kumar et al., 2005; Iason et al., 2012; Chadwick et al., 2013; Tamilselvan et al., 2014). Secondary metabolites have a broad range of biological activities: antimicrobial effects, antihelmintic properties, analgesic and anti-inflammatory actions, antihyperlipidic activity, effects on plant growth, insecticidal, insect antifeedant properties, mammalian antifeedant properties, acute mammalian toxicity, cytotoxic and antitumor properties. The level of efficacy cannot be generalized. Each compound has individual properties and therapeutic and economical significance.

\section{CLASSIFICATION OF TOXIC COMPOUNDS IN PLANTS AND MECHANISM OF ACTION}

A logical way to group poisonous plants is by their poisonous principle, which cause toxic reaction when ingested by humans and animals (Lewis, 2003). As Sekhar et al. (2012) have considered, there is a huge variety of plant poisons and it is difficult to organize "the myriad plant toxins in an understandable manner". Plant toxins can be classified based on their structural and chemical properties or according to the organ 
system in the human body, which they affect. There are also classifications where plant toxins are described based on their mechanism of action, human fatal effect or forensic criteria. Different points of view are commonly met regarding the vegetal allergens and their definition as toxic substances. The relevant researches are reviewed in this paper.

Wink has conducted relevant researches regardingsecondarymetabolites, their importance, diversity and evolution. The author chemically classified secondary metabolites (2009) into two major groups: with nitrogen (alkaloids, non-protein amino-acids, amines, cyanogenic glucosides, glucosinolates, alkamides) and without nitrogen (monoterpenes, sesquiterpenes, diterpenes, triterpenes, saponins, steroids, tetraterpenes, phenylpropanoids, coumarins, lignans, flavonoids, tannins, polyacetylenes, fatty acides, waxis, polyketides, carbohydrates, acids). Wink also reviewed plant toxins on the bases of important mechanism of action. Poisons are classified in three categories according to their oral toxicity, determined in rat experiments: class Ia - extremely hazardous (5mg or less per kg body weight); Ib - highly hazardous (5 to $50 \mathrm{mg} / \mathrm{kg}$ body weight); class II - moderately hazardous (50 to $500 \mathrm{mg} / \mathrm{kg}$ body weight) and class III - slightly hazardous (500 mg and more per kg body weight), as cited by Wink (2009) and Khajja et al. (2011). Toxins, which fall into the classes Ia, Ib and II interfere with central functions in an animal. The most poisonous substances are neurotoxins which affect the nervous system followed by cytotoxins and metabolic poisons that disturb the liver, heart, kidneys, respiration, muscles and reproduction (Wink, 2009). Poisonous plants of Europe were tabulated, with some details on their toxins and toxicology. Wink approached toxins of skin and mucosal tissues and their biochemical mode of action. The author included in that category phorbol esters, furanocoumarins, glycoside as ranunculin (precursor of protoanemonin) and calcium-oxalate needles.

Gilbert (2004) has focused on the toxicity of some of the better-known plants, organised by organ/system affected: skin, gastrointestinal, cardiovascular, nervous systems, liver and reproductive effects. Skin symptoms were explained through either an allergic antibodymediated response or through direct-acting chemicals. Crosby (2004) classified major skin allergenic vegetal compounds. Bernhoft (2010) categorised secondary metabolites on the basis of main chemical groups: glycosides, flavonoids and proanthocyanidins, tannins, mono and sesquiterpenoids and phenyl propanoids, diterpenoids, resins, lignans, alkaloids, furocoumarines and naphtodianthrones, peptides. The author mentioned medical uses of these compounds. Vegetal examples were cited. Sekhar et al. (2012) classified plant toxins on their structural and chemical properties: alkaloids, glycosidal toxins, tannins, proteins, volatile etheric layers, photosensitizing substances, antivitamines, phytoestrogens, enzyme inhibitors. The author discussed chemical effects more than structural and chemical classes. This type of classification is met to other authors also (Zanoschi et al., 1981; Ionel et al., 2000).

Gaillard and Pepin (1999) have reviewed the main toxic plants responsible for human deaths throughout the world. Forty genera and species were reported. The authors have appreciated that the total number of deaths is difficult to establish. From ornamental plants the following were included: Aconitum, Colchicum, Convallaria, Datura, Diffenbachia, Nerum oleander, Polygonatum, Ricinus. Lewis (2003) elaborated a chemical classification of vegetal toxin on the main groups: glycosides, alkaloids, lectines, resins, element and nitrate absorbtion. Khajja et al., (2011) have reviewed more than 50 indian poisonous plant species according with forensic traits: toxic parts, toxic constituents, fatal dose and fatal period.

There are great number of international books, research articles and databases which refers to poisonous plants (Huntington, 1999; Frohne and Pfänder, 2005; Johnson and Johnson 2006; Harmful garden plants in Western Australia, 2009; Dauncey, 2010; Burrows and Tyrl, 2013; McKenzie, 2012; FDA Poisonous plants database, 2014), allergic contact dermatitis to plants and plants extracts (Jovanovic and Poljacki, 2003; Al Aboud, 2011; McGovern and Barkley, 2013), guidelines for designing spaces with low allergy impact (Cariñanos and Casares-Porcel, 2011) or to gardening with asthma (Esch et al., 2001). All these references have discussed name and description of plant, poisonous parts and clinical symptoms. Comprehensive reports on plant 
secondary metabolites have been elaborated by pharmacognosists: chemical description, laboratory determinations, medical uses, toxicology of plant constituents (Ciulei et al., 1993; Mogoşanu et al., 2012).

It is fact that virtually any substances can be harmful at specific concentration and specific conditions. Exposure could be anywhere in public spaces, work environment or private homes and gardens (Finkle, 2013).

Apart from internal organs, the skin and mucosal tissues of animals and humans can also be affected by several toxins. This is done through either an allergic antibody - mediated response or through direct-acting chemicals. For an allergenic type of response, it is not the first contact that produces the reaction, but rather the next. Although not a direct protection for the plant, pollens cause an allergic response in many people (Crosby, 2004; Gilbert, 2013).

\section{POISONOUSAND ALLERGENICCOMPOUNDS IN ORNAMENTALS}

On the basis of reviewed data we consider that vegetal toxic compounds include poisonous and also allergenic bioactive chemicals. This approach is in according with the research of Gilbert (2004) and Crosby (2004). Chemical classification based on structural and chemical properties, in our opinion, is the best way to centralize and understand the secondary metabolites. These traits allow to better organize identification of these principles from vegetal extracts.

Ornamentals haven't been toxicology evaluated as single groups of plants. These plants are beauty but can be hazardous for people. Information about their risk potential for health is important in managing potential problems. Ornamentals are daily companions, inside or outside, in private or public spaces. Poisonous compounds in ornamentals are tabulated (tab.1): chemical class, type of compounds and typical vegetal elicitors are mentioned. Irritant and alergenic compounds in ornamentals are tabulated (tab.2). Chemical compounds, typical elicitors and class of dermatotoxicity and possible sensitization are mentioned.

Floral species usually produce and accumulate a mixture of secondary metabolites with possible additive or even synergetic properties and activi- ties. In Table 3, common toxic ornamentals from our habitat (poisonous and allergenic) are tabulated, with some details of their toxins and toxicology. Some non-native plants, even shrubs in their area of origin, were included on the basis of their high presence as house plants. Allergenic and poisonous weeds without ornamental characteristics were not included in the paper, despite their allergenicity (Ambrosia sp., Artemisia sp. etc.) or their toxicity (Atropa belladonna, Conium maculatum etc.).

Our classifications should of use to botanists, chemists, horticulturists, health professionals, pharmacognosists. Romanian poisonous ornamental plant databases is subject of interest for landscape architects and landscape engineers, horticulturists, floral designers, enthusiasts in gardening and those with a concern for threats to human health in the environment.

Common toxic ornamental plants databases include general data: scientific and family name, common name, hazardous plant parts, toxicity class, hazardous active principles, class of symptoms. There are also some specific information we considered be of practical importance: human exposure, plant uses, human fatal dose and fatal period (if reported), occupational risk factor (if known). Sixty native ornamental plants (Şelaru, 2007) and ten nonnative ornamental houseplant were analysed. These centralised data could be a starting point for a national databases (poisonous plant information system).

\section{OCCURRENCE AND FUNCTION OF SECONDARY METABOLITES IN PLANTS}

Plants have involved the strategy to produce bioactive natural products as a means of defence against herbivores and microbes (Wink, 2009). Biosynthesis, transport and storage of secondary metabolites are usually complex processes in plants (Wink, 2009; Capon, 2011; Iason et al., 2012).

In some species, the poisonous constituents occur throughout the whole plant. In others they are concentrated in one or more parts (Ciulei et al., 1993; Mogoşanu et al., 2012; Wink, 2009). The biosynthesis of secondary metabolites differ in terms of quantitative level, grade of toxicity, chemical structures, depending on thegeographical and climate conditions (temperature, humidity, light), characteristics of soil, agrotechniques 
Tab. 1. Notable poisonous compounds in ornamentals

\begin{tabular}{|c|c|c|}
\hline \multicolumn{2}{|l|}{ Chemical compounds } & \multirow{2}{*}{$\begin{array}{l}\text { Typical elicitors } \\
\text { (example) }\end{array}$} \\
\hline Class & Type & \\
\hline \multicolumn{3}{|l|}{ 1. Alkaloids } \\
\hline \multirow{6}{*}{ True alkaloids } & $\begin{array}{l}\text { tropane alkaloids (hyoscyamine, atropine, } \\
\text { scopolamine) }\end{array}$ & $\begin{array}{l}\text { Atropa belladonna, Datura stramonium, } \\
\text { Hyosciamus niger }\end{array}$ \\
\hline & $\begin{array}{l}\text { pyridine alkaloids (ricinine) and } \\
\text { piperidine alkaloids (coneine) }\end{array}$ & $\begin{array}{l}\text { Ricinus communis } \\
\text { Conium maculatum }\end{array}$ \\
\hline & pyrrolizidine alkaloids (senecionine) & Senecio sp. \\
\hline & quinolizidine alkaloids (lupinine) & Lupinus sp. \\
\hline & $\begin{array}{l}\text { isoquinoline alkaloids (curare/morphine, } \\
\text { codeine) and amaryllis alkaloids } \\
\text { (galantamine, nivalidine, narcissine) }\end{array}$ & $\begin{array}{l}\text { Capsicum sp./Papaver sp. } \\
\text { Galanthus nivalis } \\
\text { Narcissus poeticus }\end{array}$ \\
\hline & $\begin{array}{l}\text { indole alkaloids (harmine, ergotamine, } \\
\text { vincamine) }\end{array}$ & $\begin{array}{l}\text { Passiflora sp., Ipomoea sp., } \\
\text { Vinca sp. }\end{array}$ \\
\hline \multirow{2}{*}{ Protoalkaloids } & colchicine, colchamine & Colchicum autumnale, Gloriosa superba \\
\hline & capsaicin, dihydrocapsaicin & Capsicum annuum \\
\hline Pseudoalkaloids & diterpenes alkaloids (aconitine/delphinine) & Aconitum sp/Delphinium elatum \\
\hline \multirow{3}{*}{ 2.Peptides (as lectines) } & ricin, abrin & Ricinus communis \\
\hline & crotine & Croton sp. \\
\hline & snow-drop lectine & Gallanthus nivalis \\
\hline \multicolumn{3}{|l|}{ 3. Glycosides } \\
\hline \multirow{6}{*}{ Cardiac (steroidal) glycosides } & digoxin, digitoxin & Digitalis purpurea, D. lanata \\
\hline & convalatoxin & Convallaria majalis \\
\hline & adonitoxin & Adonis vernalis \\
\hline & oleandrine & Nerium oleander \\
\hline & proscillardin A & Scilla maritima \\
\hline & hellebrim, hellebrigenin & Helleborus niger \\
\hline \multirow{2}{*}{ Thioglycosides (glucosinolates) } & gluco-tropeolin & Tropaeolum majus \\
\hline & sinigroside & Brassica sp. \\
\hline Cyanogenic glycosides & aroin & Arum sp. \\
\hline \multirow{4}{*}{ Saponins } & tigonin & Digitalis lanata \\
\hline & gitonin & Digitalis purpurea \\
\hline & triterpene saponins & Primula sp. \\
\hline & saponariosides A, B & Saponaria officinalis \\
\hline Antraquinone glycosides & antron, anthranol, aloin A, B & Aloe sp. \\
\hline Hydroquinone glycosides & arbutin & Bergenia crassifolia \\
\hline Alcoholic glycosides & salicin, salicilin derivatives & Primula sp. \\
\hline \multicolumn{3}{|c|}{ 4. Aromatic compounds (other than glycosides) } \\
\hline \multirow{2}{*}{ Phenols and derivatives } & hydroquinone and derivatives & Calluna sp. \\
\hline & salligenin & Primula sp. \\
\hline \multirow[b]{2}{*}{ Benzopyran and derivatives } & coumarins and chromones & Angelica arhangelica, Citrus sp. \\
\hline & $\begin{array}{l}\text { flavonoids (flavan, flavone, isoflavone, } \\
\text { catechins etc.) }\end{array}$ & $\begin{array}{l}\text { Amarantaceae, Asteraceae, } \\
\text { Euphorbiaceae, Iridaceae }\end{array}$ \\
\hline Tannins & catehic, galic & Geum urbanum, Potentilla erecta \\
\hline Antraquinones and derivatives & hypericin & Hypericum perforatum \\
\hline 5. Allyl derivatives & allicin & Allium sp. \\
\hline 6. Isoprenoides & $\begin{array}{l}\text { monoterpenes, diterpernes, triterpenes, } \\
\text { tetraterpenes, sesquiterpenes (luian, ambein, } \\
\text { arteglasin A etc.) }\end{array}$ & Inula helenium, Euphorbia sp. \\
\hline 7. Other classes & amines, acids, essential oils etc. & Citrus, Rosa, Dieffenbachia \\
\hline
\end{tabular}


Tab. 2. Irritant and allergenic compounds in ornamentals

\begin{tabular}{|c|c|c|c|c|c|}
\hline \multicolumn{3}{|c|}{ Chemical compounds } & \multirow{2}{*}{$\begin{array}{l}\text { Typical elicitors } \\
\text { (example) }\end{array}$} & \multirow{2}{*}{$\begin{array}{l}\text { Class of } \\
\text { Dermato- } \\
\text { toxicity }\end{array}$} & \multirow{2}{*}{$\begin{array}{l}\text { Sensiti- } \\
\text { zation }\end{array}$} \\
\hline Class & & Example & & & \\
\hline \multicolumn{2}{|c|}{ Esters of diterpene polyols } & phorbol esters & $\begin{array}{l}\text { Euphorbia sp. } \\
\text { (E.pulcherima) }\end{array}$ & \multirow{7}{*}{$\begin{array}{l}\text { Irritant } \\
\text { contact } \\
\text { dermatitis } \\
\text { (ICD) }\end{array}$} & \multirow{7}{*}{ No } \\
\hline \multirow{3}{*}{$\begin{array}{l}\text { Organo sulphur } \\
\text { compounds }\end{array}$} & & $\begin{array}{l}\text { simalbim, } \\
\text { gluconapin, simgrin }\end{array}$ & Brassica sp. & & \\
\hline & Glucosinolates & $\begin{array}{l}\text { glucoibrin, } \\
\text { glucoibervirin }\end{array}$ & $\begin{array}{l}\text { Tropaeolum majus, } \\
\text { Matthiola incana, } \\
\text { Iberis sempervirens }\end{array}$ & & \\
\hline & $\begin{array}{l}\text { Allyl } \\
\text { derivatives }\end{array}$ & $\begin{array}{l}\text { allicin (diallyl } \\
\text { thiosulfinate) and } \\
\text { analogs }\end{array}$ & Allium sp. & & \\
\hline \multicolumn{2}{|l|}{ Lactones } & protoanemonin & $\begin{array}{l}\text { Anemone sp., Ranunculus sp., } \\
\text { Caltha palustris, } \\
\text { Pulsatilla vulgaris }\end{array}$ & & \\
\hline \multicolumn{2}{|c|}{ Amines and amides } & capsaicin & Capsicum annuum & & \\
\hline \multicolumn{2}{|l|}{ Calcium oxalate } & $\begin{array}{l}\text { calcium oxalate } \\
\text { crystals (sand, } \\
\text { aggregate, sharp } \\
\text { needles) }\end{array}$ & $\begin{array}{l}\text { Dieffenbachia sp., } \\
\text { Anthurium andreanum, } \\
\text { Zantedeschia aethiopica, } \\
\text { Narcissus sp. (bulbs) }\end{array}$ & & \\
\hline \multicolumn{2}{|l|}{ Urushiods } & resorcinol & Phillodendron sp. & \multirow{4}{*}{$\begin{array}{l}\text { Allergic } \\
\text { contact } \\
\text { dermatitis } \\
\text { (ACD) }\end{array}$} & \multirow{4}{*}{ Yes } \\
\hline \multicolumn{2}{|c|}{ Quinones and hydroquinones } & primin & $\begin{array}{l}\text { Primula sp. } \\
\text { (P. obconica) }\end{array}$ & & \\
\hline \multicolumn{2}{|l|}{ Lactones } & $\begin{array}{l}\text { alantolactone, } \\
\text { arteglasin A, } \\
\text { carabron, } \\
\text { niveusin A, } \\
\text { tulipalin A, } \\
\text { tuliposid A }\end{array}$ & $\begin{array}{l}\text { Inula helenium, } \\
\text { Dendranthema sp, Primula } \\
\text { sp., } \\
\text { Arnica longifolia, } \\
\text { Helianthus annuus, } \\
\text { Tulipa sp., } \\
\text { Alstroemeria sp. }\end{array}$ & & \\
\hline \multicolumn{2}{|c|}{$\begin{array}{l}\text { Essential oils (complex mixtures } \\
\text { with aliphatic and alicyclic } \\
\text { compounds) }\end{array}$} & $\begin{array}{l}\text { geraniol, } \\
\text { hydroxycitronellal, } \\
\gamma \text {-methylionone, } \\
\text { limonene }\end{array}$ & $\begin{array}{l}\text { Geranium sp., } \\
\text { Rosa sp., } \\
\text { Viola odorata, } \\
\text { Citrus sp. }\end{array}$ & & \\
\hline \multicolumn{2}{|c|}{$\begin{array}{l}\text { Furocoumarins (benzopyran } \\
\text { derivatives) }\end{array}$} & $\begin{array}{l}\text { angelicin, } \\
\text { bergapten, } \\
\text { psoralen, } \\
\text { pimpinellin }\end{array}$ & $\begin{array}{l}\text { Angelica arhangelica, } \\
\text { Citrus sp. }\end{array}$ & \multirow[t]{3}{*}{$\begin{array}{l}\text { Photo- } \\
\text { toxicity } \\
\text { (PT) }\end{array}$} & \multirow[t]{3}{*}{ No } \\
\hline \multicolumn{2}{|c|}{ Polyhydroxy quinone } & hypericin & Hypericum perforatum & & \\
\hline \multicolumn{2}{|l|}{ Terthienyls } & $\alpha$-therhienyl & Tagetes patula & & \\
\hline
\end{tabular}




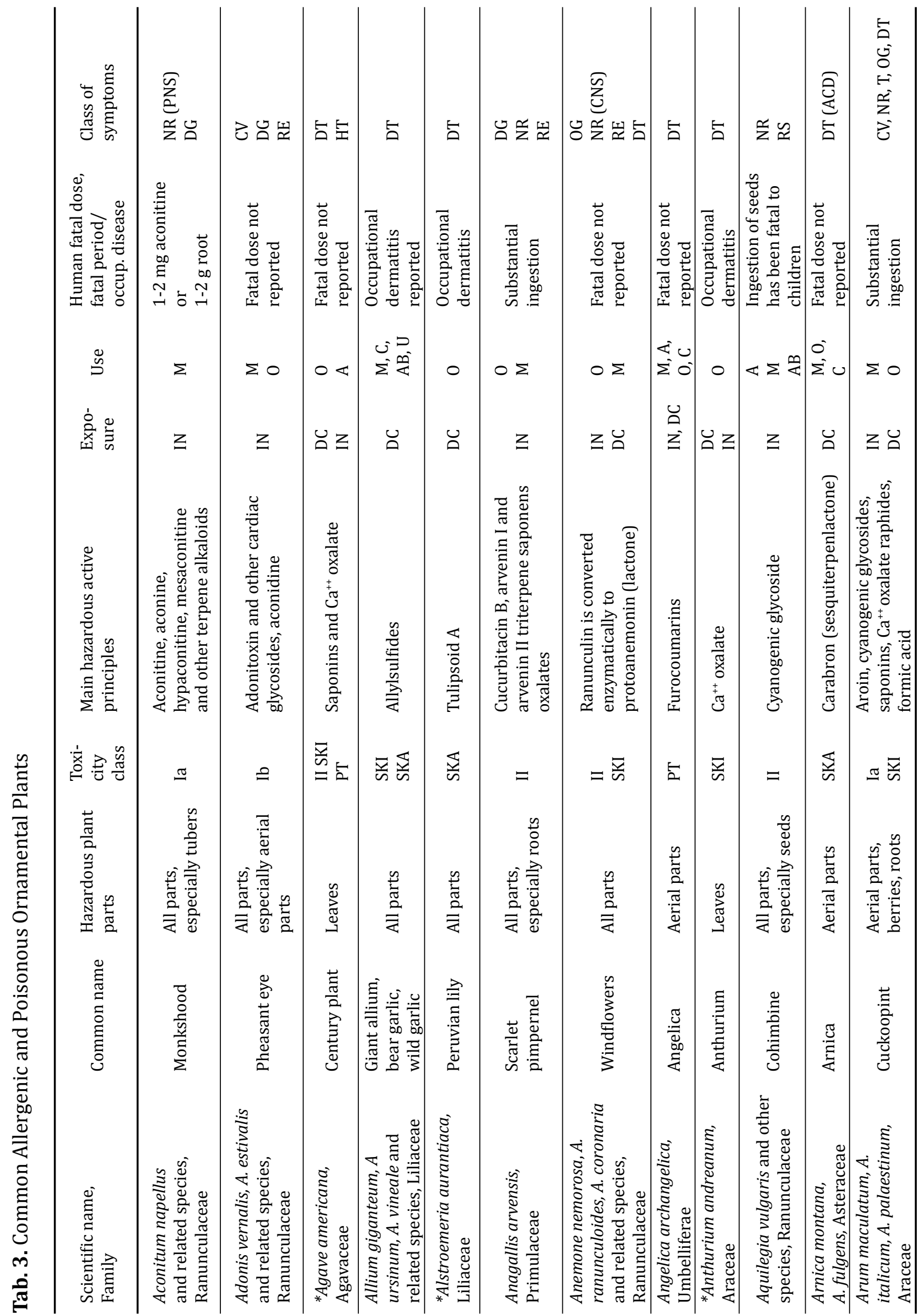




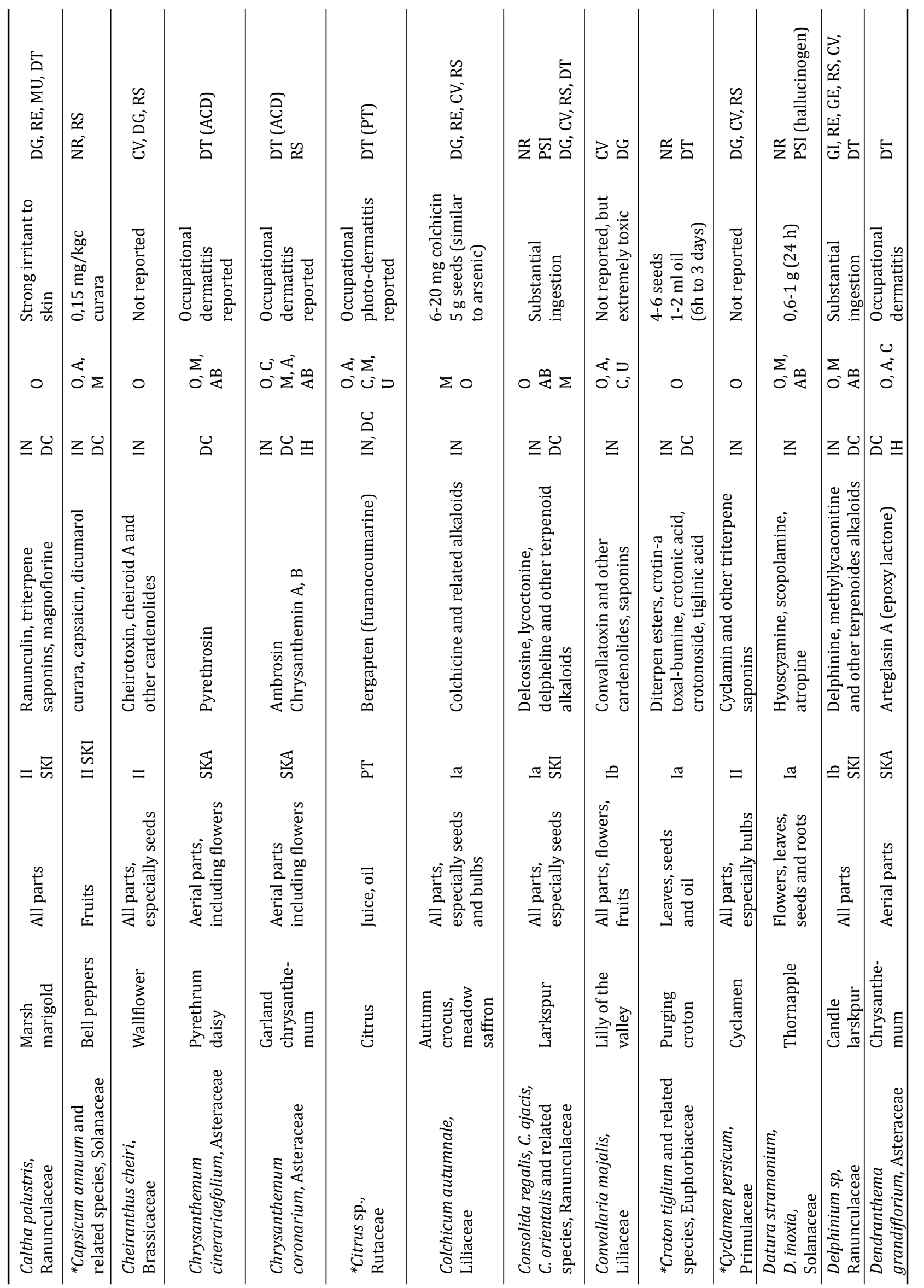




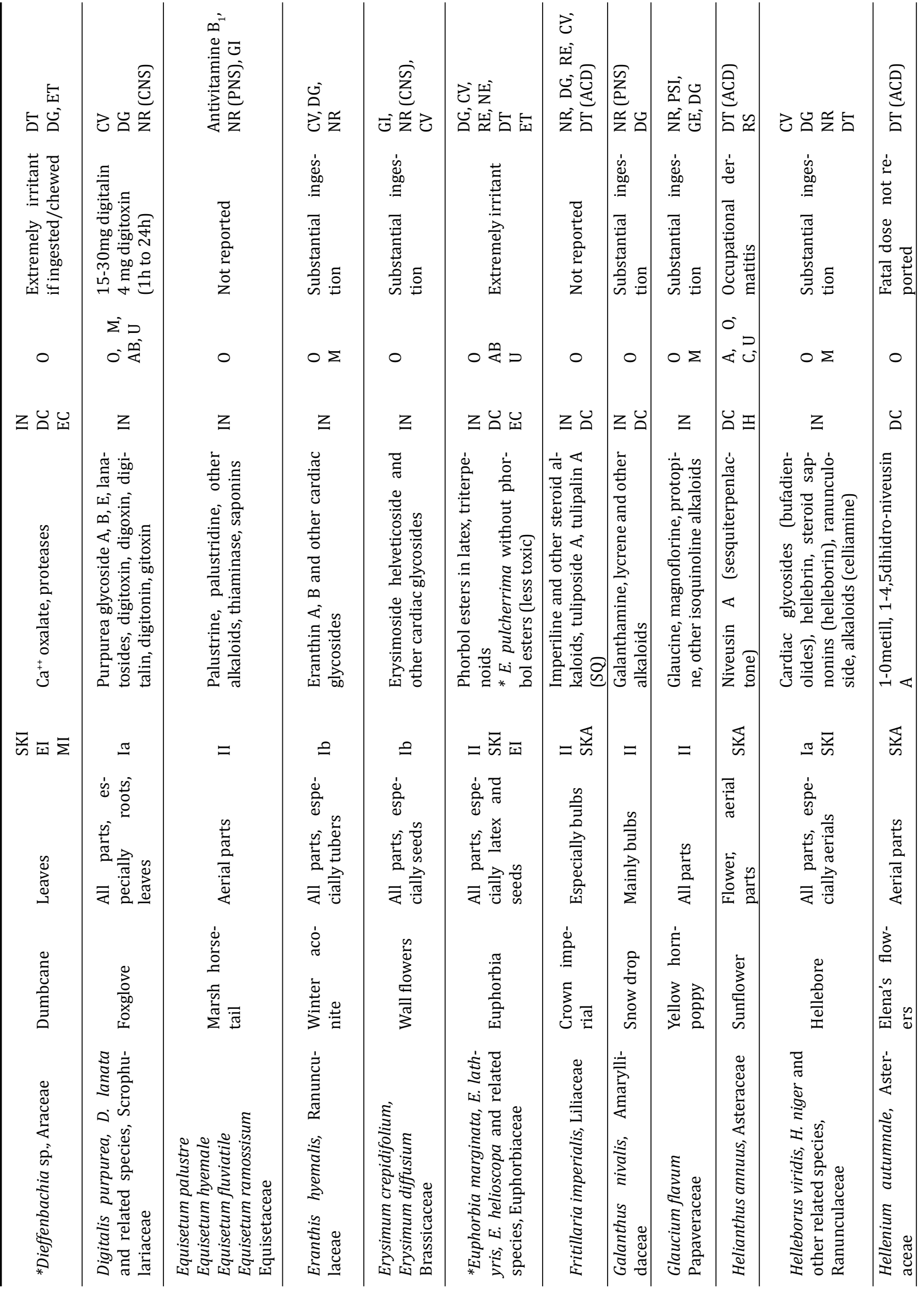




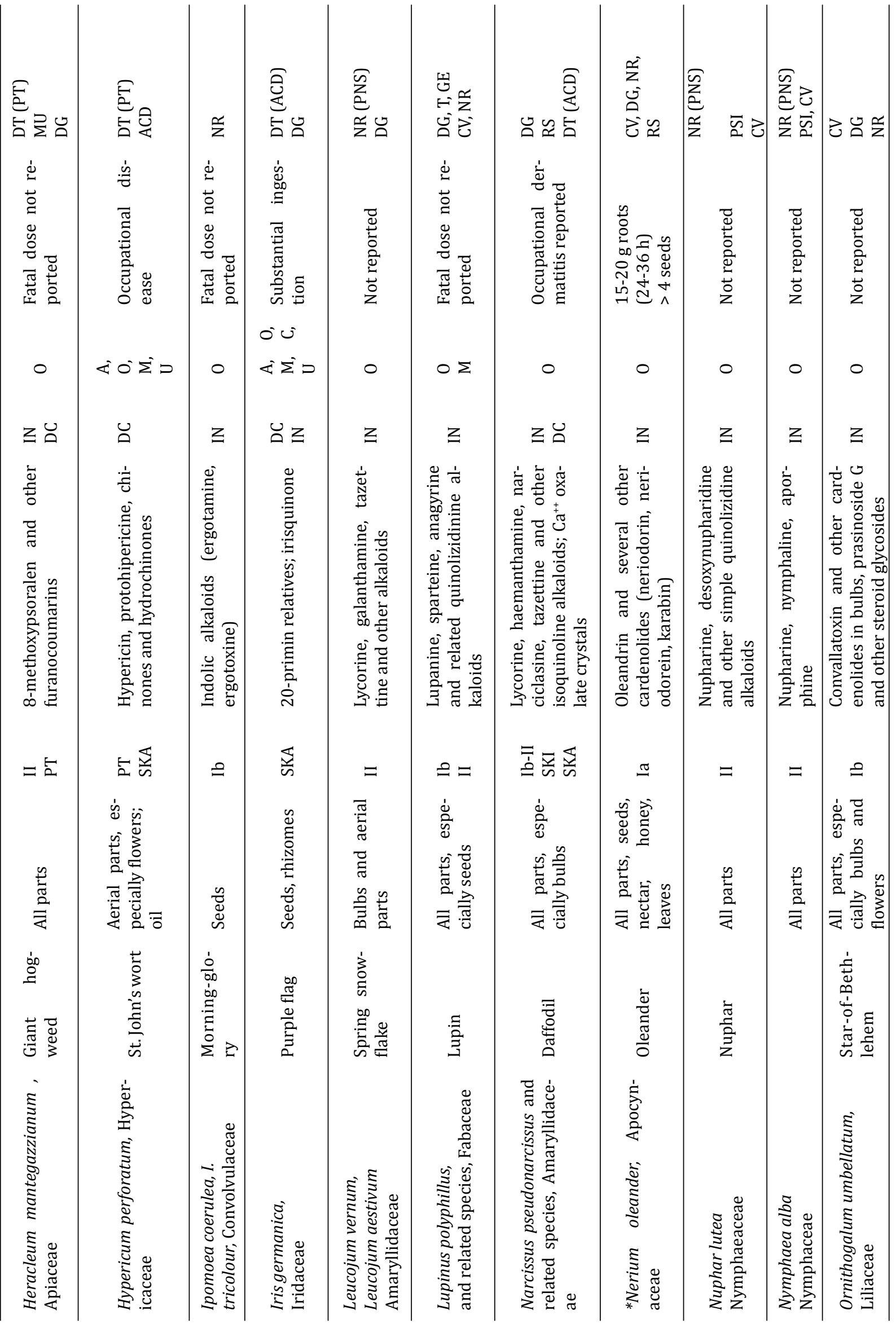




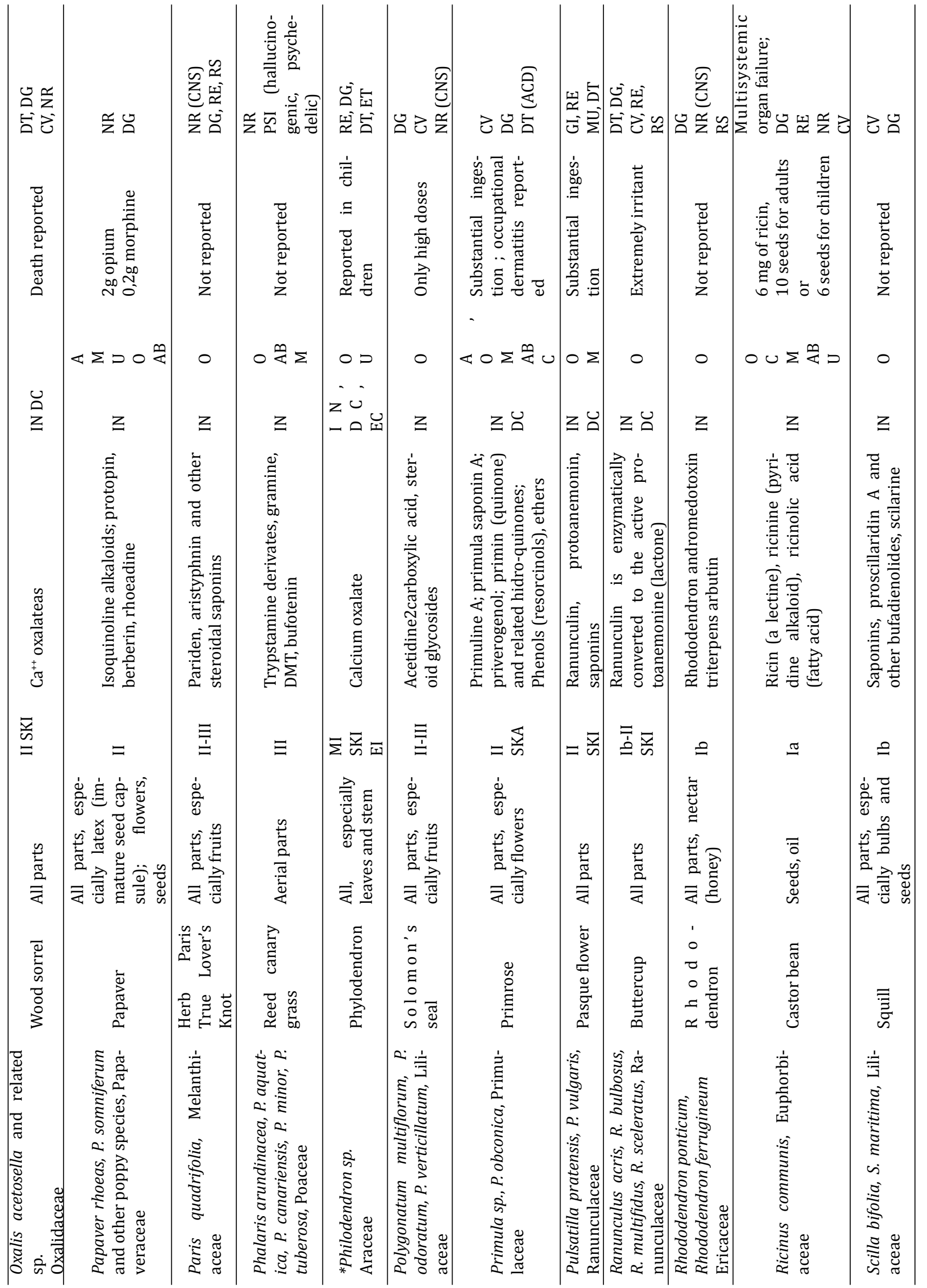




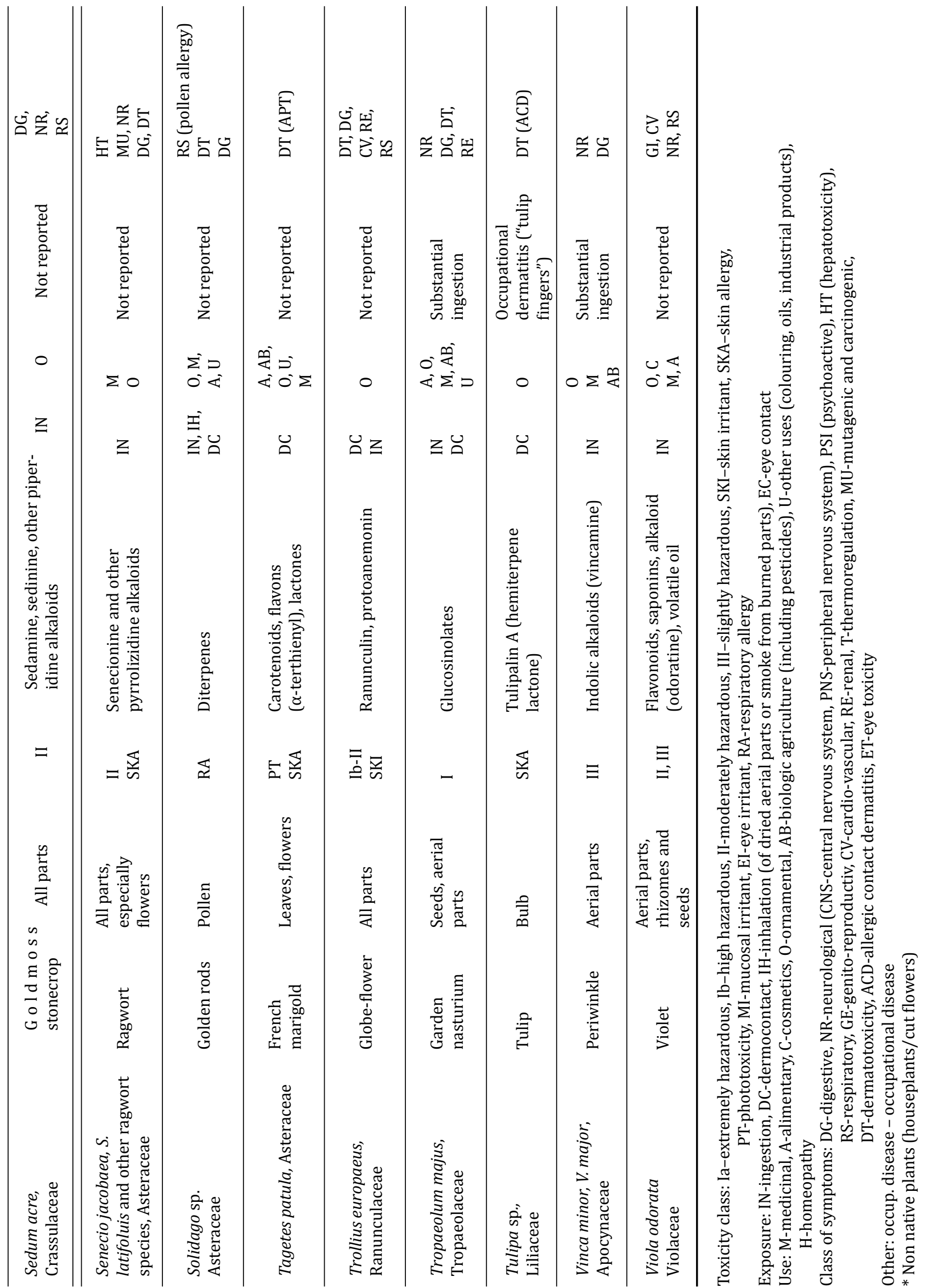


(water supply, fertilization, time of harvesting), plant age, species and sometimes depending on the microbiological invasions (bacteria, viruses, fungi) (Kumar et al., 2005; Hansen and Wold, 2010; Nasim et al., 2010, Adeyemi, 2011; Fraga, 2013).

Sahoo et al., (2012) have evaluated the variations in the total amount of secondary metabolites during different seasons in India, in five important valuable medicinal plants. The results revealed that maximum amount of secondary metabolites (total alkaloids and phenols) were observed during summer, while minimum in rainy season. Growth parameters including plant height, herb fresh and dry weights were reduced significantly with increasing water stress levels in a study conducted by Azhar et al., (2011). In the same study, total phenolic contents and chlorophyll contents increased under water stress conditions. Seasonal variation in the production of secondary metabolites and antimicrobial activity were observed in two Brazilian plant species (Chaves et al., 2012). Growth regulators had significant effects on the secondary metabolite production (Karalija and Parić, 2011). After addition of plant growth regulators to the medium (BA, IBA) elicitations of phenolic compounds was recorded and the same treatment showed a decrease in monomeric anthocyanins.

Species of plants vary in their content of toxic compounds owing to unpredictable extrinsec and genetic factors (Kingsbury, 2013; Azeez and Ibrahim, 2013).

\section{PLANT POISONING}

Human fatal cases are the fact of about 40-50 genera throughout the world (Gaillard and Pepin, 1999). Usually, undesired effects are registered by accident. Poisoning by plant is underestimated worldwide.

It is interesting to note that the plants most commonly enquired about at Poison Control Centres in Switzerland and the United States are only 5 genus (Euphorbia, Diffenbachia, Pyracantha, Ilex and Philodendron) and they are the common causes of poisoning in both areas (Frohne and Pfänder, 2005). The Swedish Poison Information Centre (PIC) received 4514 inquiries about children exposed to plants in 2008 . Ornamentals commonly involved were: Convalaria majalis, Digitalis purpurea, Spathiphyllum wallissi, Euphorbia pulcherrima, Crassula sp., Epipremum aureum, Dieffenbachia sp., Zamioculcas zamifolia (Spillum and Muan, 2010). In New Zealand National Poison Centre 15 plants are commonly reported (child and adult enquiries). Ornamentals involved are: Zantedeschia aethiopica, Euphorbia sp., Spathiphyllum sp., Agapanthus sp., Iris foetidissima, Colocasia esculentum, Narcissus sp., Nerium oleander, Dgitalis purpurea (Slaughter et al., 2012).

\section{SUMMARY AND PERSPECTIVES}

As mentioned in the previous sections, ornamental plants may be hazardous for human health through vegetal constituents (irritant, allergenic or poisonous). It is important to know these plants and their biochemical products in order to avoid intoxication or skin exposure in humans (especially children), pets or livestock.

Toxic plants or their compounds are also used for different purposes. Secondary metabolites are source in the production of several valuable products (agrochemicals, biopestisides, colours, flavours, fragrances, food additives and pharmaceuticals). The commercial value of plant secondary metabolites have been the main reason for the enormous research effort put into understanding and manipulating their biosynthesis and the cultivation of specific plants including ornamentals. Several investigation have shown that there is a large genetic variation for concentration of these substances and this variation can be exploited.

We think that more effort should be invested in research on toxic compounds of ornamental plants. The risk to health impose health and safety regulations at work, the need to inform population and the evaluation of natural remedies and cosmetic products from plants through an poisonous and allergenic perspective. Many ornamentals represent a valuable source of highly biologically active compounds and could have greater economic uses. A national poisonous plants databases will allow people to access information, to avoid undesired effects and to increase biosecurity in human environment.

Aknowledgements. This paper was published under the frame of European Social Fund, Human Resources Development Operational Programme 2007-2013,projectno.POSDRU/159/1.5/S/132765. 


\section{REFERENCES}

1. Adeyemi MM H (2011). A review of Secondary Metabolites from Plant Materials for Post Harvest Storage. Int. J. Pure Appl. Sci. Technol. 6(2):94-102.

2. Al Aboud MA (2011). Plants and dermatology: A panoramic view. Journal of Pakistan Association of Dermatologists 21:55-57.

3. Azeez AH, Ibrahim K (2013). Effect of Biotic Elicitors on Secondary Metabolite Production in Cell Suspension of Hyrericum triquetrifolium Turra. Bulletin UASVM Horticulture 70(1):26-33.

4. Azhar N, Hussain B, Ashraf MY, Abbasi KY (2011). Water stress mediated changes in growth, physiology and secondary metabolites of Desi Ajwain (Trachyspermum ammi L.). Pak. J. Bot. 43:15-19.

5. Bernhoft $A$ (2010). A brief review on bioactive compounds in plants, p. 11-19. In: Bernhoft A (Ed.). Bioactive compounds in plants - benefits and risks for man and animals. The Norvegian Accademy of Science and Letters. AIT Otta AS, Oslo.

6. Burrows GE, Tyrl RJ (2013). Toxic Plants of North America. $2^{\text {nd }}$ ed. Wiley-Blackwell, US, 1390p.

7. Capon B (2011). Botany for Gardeners. $3^{\text {rd }}$ ed. Timber Press, Portland, Oregon, 268 p.

8. Cariñanos P, Casares-Porcel M (2011). Urban green zones and related pollen allergy: A review. Some guidelines for designing spaces with low allergy impact. Landscape and Urban Planning 101:205-214.

9. Chadwick M, Trewin H, Gawthrop F, Wagstaff C. (2013) Sesquiterpeneoids lactones: Benefits to Plants and People. Int J Mol Sci 14:12780-12805.

10. Chaves TP, Santana CP, Véras G, Brandăo DO, Felismino DC, Medeiros ACD, Trovão DM de BM (2012). Seasonal variation in the production of secondary metabolites and antimicrobial activity of two plant species used in Brazilian traditional medicine. African Journal of Biotechnology 12(8): 847-853.

11. Ciulei I, Grigorescu E, Stănescu U (1993). Plante medicinale, fitochimie şi fitoterapie. Vol. I, II, Editura Medicală, București, 732 p., 740 p.

12. Crosby DG (2004). The Poisoned Weed - Plants Toxic to Skin. Oxford University Press, New York, 266 p.

13. Dauncey EA (2010). Poisonous plants - a guide for parents and childcare providers. Kew Publishing, Kew, 172p.

14. Esch R, Hartsell C, Crenshaw R, Jacobson R (2001). Common Allergenic Pollens, Fungi, Animals and Arthropods. Clinical Reviews in Allergy and Immunology 21: 261-292.

15. Finkle A (2013). Understanding Toxic Plant Exposure in Habitat Restoration and Environmental Management. Safe Harbor Environmental Management. Safe harbour Environmental Services.

16. Fraga BM (2013). Natural Sesquiterpenoids. Natural product reports. 30:1226-1264.

17. Frohne D, Pfänder HJ (2005). Poisonous plants: a handbook for doctors, pharmacists, toxicologists, biologists and veterinarians. $2^{\text {nd }}$ ed. Taylor $\&$ Francis, 450 p.
18. Gaillard Y, Pepin G (1999). Poisoning by plant material: review of human cases and analytical determination of main toxins by high-performance liquid chromatography(tandem) mass spectrometry. Journal of Cromatography B 733:181-229.

19. Gavrilescu E (2008). Noţiuni generale de ecotoxicologie. Sitech, Craiova, 267p.

20. Gilbert SG (2004). Animal and Plant Toxins, p.155-174. In: A Small Dose of Toxicology - The Health Effects of Common Chemicals. $1^{\text {st }}$ ed. CRC Press, Boca Raton, Florida.

21. Goldberg A, Confino-Cohen R, Waisel Y (1998). Allergic responses to pollen of ornamental plants: High incidence in the general atopic population and especially among flower growers. The Journal of Allergy and Clinical Immunology 102:210-214.

22. Hansen M, Wold AB (2010). Contents of bioactive compounds in food plants as affected by traditional breeding and environmental factors, p. 212-221. In: Bernhoft A (Ed.). Bioactive compounds in plants - benefits and risks for man and animals. The Norvegian Accademy of Science and Letters. AIT Otta AS, Oslo.

23. Huntington L (1999). Creating a low-allergen garden. Mitchell Beazley, London, $127 \mathrm{p}$.

24. Iason GR, Dicke M, Hartley S (2012). The integrative roles of plants secondary metabolites in natural systems: a synthesis, p. 1-10. In: Iason GR, Dicke M, Hartley S. (Eds). The Ecology of Plant Secondary Metabolites: From Genes to Global Processes (Ecological Reviews). Cambridge University Press.

25. Ionel A, Zanoschi V, Pascal P (2000). Plante furajere, toxice şi medicinale. Editura A92, Iaşi, 488p.

26. Jack AR, Norris PL, Storrs FJ (2013). Allergic Contact Dermatitis to Plant Extracts in Cosmetics. Semin Cutan Med Surg 32:140-146.

27. Johnson A, Johnson S (2006). Garden plants poisonous to people. Primefacts 359: 1-12

28. Jovanovic M, Poljacki M (2003). Compositae dermatitis. Med Pregl 56(1-2):43-49.

29. Karalija E, Parić A (2011). The effect of BA and IBA on the secondary metabolite production by shoot culture of Thymus vulgaris L. Byologica Nyssana 2(1): 29-35.

30. Khajja BS, Sharma M, Singh R, Mathur GK (2011). Forensic Study of Indian Toxicological Plants as Botanical Weapon (BW): A Review. J Environment Analytic Toxicol 1:112. doi:10.4172/2161-0525.1000112.

31. Kingsbury JM (2013). The Problem of Poisonous Plants. p. 1-6. In: Kinghorn AD (Ed.). Toxic Plants. Columbia University Press.

32. Kumar A, Singh SP, Bhakuni RS (2005). Secondary metabolites of Chrysanthemum genus and their biological activities. Current Science 89(9):1489-1501.

33. Lăncrăjan I (2012). Ecotoxicologie: Curs Universitar. Editura Ecou Transilvan, Cluj-Napoca, 419 p.

34. Le Coz CJ, Ducombs G, Paullsen E (2011). Plants and plant products, p. 873-925. In: Johansen JD, Frosch PJ, Lepoittevin JP (Eds.). Contact Dermatitis. $5^{\text {th }}$ ed. Springer, Heidelberg 
35. Lewis HV (2003). Medical Botany: Plants Affecting Human Health. $2^{\text {nd }}$ ed. John Wiley\&Sons. 812p.

36. McGovern TW, Barkley MT (2013). Botanical Dermatology. In: Drugge R, Dunn HA, (Eds.). Electronic Textbook of Dermatology [http://telemedicine.org/stamford.htm].

37. McKenzie R (2012). Austrilia's Poisonous Plants, Fung and Cyanobacteria: A guide to species of medical and veterinary importance. CSIRO Publishing.

38. Mogoşanu GD, Bejenaru LE, Popescu H. (2012) Farmacognozie-Fitoterapie. Memorator. Sitech, Craiova, $478 \mathrm{p}$.

39. Nasim SA, Aslam J, Kapoor R, Ahmad Khan S. (2010). Secondary metabolites production through biotechnological intervention: A review. Emir J FoodAgric 22(3):147-161.

40. Nelson L (2003). Florists and Groundskeepers, p. 174184. In: Occupational industrial and environmental toxicology. $2^{\text {nd }}$ ed. Elsevier Health Sciences, Paris.

41. Philip M (2009). Guidelines for writing a Review Article. Zurich-Basel Plant Science Center. [http://www. plantscience.ethz.ch/education/Masterscourses/ Scientific-Writing].

42. Piirila P (1994). Occupational asthma caused by decorative flowers: review and case reports. Int Arch Occup Environ Health 66:131-136.

43. Prisăcaru C, Burlacu AI (2005). Plante medicinale şi toxice. Editura "Ion Ionescu de la Brad”, Iaşi, 344p.

44. Rozas-Munõz E, Lepoittevin JP, Pujol RM, GimenezArnau A (2012). Allergic Contact Dermatitis to Plants, Understanding the Chemistry will help our Diagnostic Approach. Actas Dermosifiliogr. 103:456-477.

45. Sahoo KP, Kasera Pawan K, Mohammed Sher (2012). Secondary metabolites produced during different seasons in some arid medicinal plants. Asian Journal of Plant Science and Research, 2(6):650-652.

46. Sekhar C.J, Sandhya S, Vinod K.R, Banji D, Sudhakar K, Chaitanya R, (2012). Plant toxins-useful and harmful effects. Hygeia JD Med 4(1):79-90.
47. Slaughter RJ, Beasley DMG, Lambie BS, Wilkins GT, Schep LJ (2012). Poisonous plants in New Zealand: a review of those most commonly enquired about to the National Poisons Centre. The New Zealand Medical Journal 125(1367):87-118.

48. Spillum BJ, Muan B (2010). Human plant poisoning in the Nordic countries - experiences from the Poisons Information Centres. p. 44-53. In: Bernhoft A (Ed.). Bioactive compounds in plants - benefits and risks for man and animals. The Norvegian Accademy of Science and Letters. AIT Otta AS, Oslo.

49. Selaru E (2007). Cultura florilor de grădină. Editura Ceres, București, $831 \mathrm{p}$.

50. Tamilselvan N, Thirumalai T, Shyamala P, David E (2014). A review of some poisonous plants and their medicinal values. Journal of Acute Disease 3(2): 85-89.

51. Wink M (2009). Mode of action and toxicology of plant toxins and poisonous plants. Mitt Julius-Kuhn Inst 421:93112.

52. Wink M (2011). Occurrence and Function of Natural Products. In: Pezzuto JM, Kato MJ (Eds.). Phytochemistry and Pharmacognosy, Encyclopedia of Life Support Systems (EOLSS), Developed under the Auspices of the UNESCO, Eolss Publishers, Paris, France [http://www. eolss.net]

53. Zanoschi V, Turenschi E, Toma M (1981). Plante toxice din România. Editura Ceres, Bucureşti, 374p.

54. United States. US Department of Health \& Human Services (2014). FDA Poisonous plants database. US Food and Drug Administration [http://www.accessdaa.fda. gov/scripts/plantox]

55. United Nations (2011). Globally Harmonized System of Classification and Labelling of Chemicals (GHS). $4^{\text {th }}$ rev ed. New York, Geneva.

56. Australia. Department of Agriculture and Food. (2009). Harmful garden plants in Western Australia. Bulletin no.4641. 